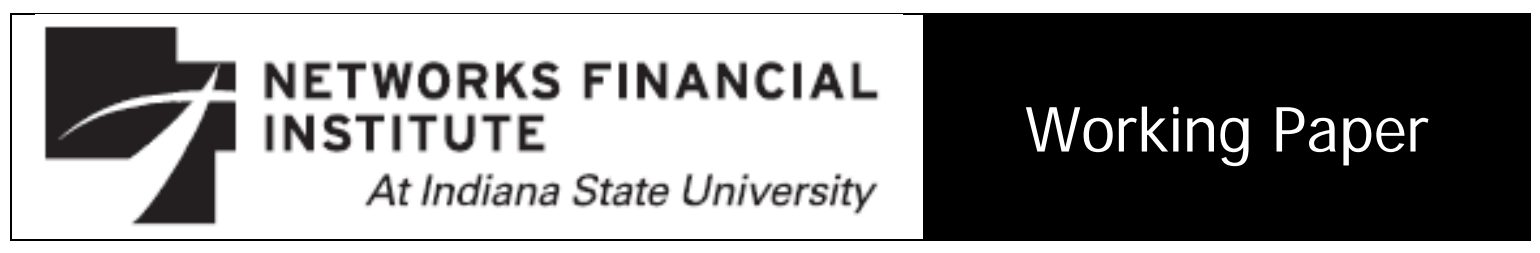

2009-WP-14

December 2009

\title{
U.S. Monetary Policy and Stock Prices: Should the Fed Attempt to Control Stock Prices? John A. Tatom
}

Abstract: This article rejects the linkages in proposals that the Federal Reserve Bank (Fed) target equity prices. The real federal funds rate (RFF) and stock prices (SP) are uncorrelated; causality tests show a positive effect of SP on RFF and a negative effect of SP on RFF. These results occur as part of the dynamics of a negative cointegrated relationship between SP and RFF. A theoretically expected inverse relation between SP and inflation accounts for the results. The negative effect of SP on FF is also confirmed in a Taylor Rule estimate. Higher stock prices anticipate lower, not higher, inflation.

About the Authors: John A. Tatom is the Director of Research at Networks Financial Institute at Indiana State University and Associate Professor of Finance at Indiana State University. He has published widely on international and domestic monetary and fiscal policy issues, especially inflation, capital formation, productivity and growth; the macroeconomics of supply, especially oil and energy price shocks; the relationship of exchange rate movements to international competitiveness, capital flows, trade, and international economic policy; and on financial innovations and their effects on monetary policy and the economy, among other areas.

Keywords: Monetary Policy, Bubbles, Asset Prices, Inflation.

J EL Classification: E52, E58, E32, G12.

This is a preliminary draft. Comments are welcome. Please do not cite without the author's permission. The author is indebted to Kevin Kliesen and Tim Opiela for helpful comments on an earlier draft.

The views expressed are those of the individual author(s) and do not necessarily reflect official positions of Networks Financial Institute. Please address questions regarding content to J ohn A. Tatom at john.tatom@isunetworks.org. Any errors or omissions are the responsibility of the authors. NFI working papers and other publications are available on NFI's website (www.networksfinancialinstitute.org). Click "Thought Leadership" and then "Publications/Papers." 


\section{U.S. Monetary Policy and Stock Prices: Should the Fed Attempt to Control Stock Prices?}

The boom-bust in stock prices since the mid-1990s and growing ownership of equities by households, both in numbers and in portfolio share, focused policy-makers' and analysts' attention on the so-called "wealth effect" of stock prices on spending. It also led to calls for the Federal Reserve (Fed) to take stock prices into account in the conduct of monetary policy, in the extreme case, to target stock prices to stabilize the economy. One major study, Cecchetti, Genberg, Lipsky and Wadhwani (2000), concluded:

A central bank concerned with hitting an inflation target at a given time horizon, and achieving as smooth a path as possible for inflation, is likely to achieve superior performance by adjusting its policy instrument not only to inflation or its inflation forecast and the output gap, but to asset prices as well.

Chairman Greenspan’s 1996 speech expressing concern for irrational exuberance began a preoccupation with stock price developments as stock prices rose and then later when they fell. Outside observers readily concluded that the Fed was concerned with stabilizing the course of stock prices. ${ }^{1}$

Not surprisingly, when stock prices began a long period of decline in spring 2000, attacks on the Fed escalated, with critics blaming the Fed for a deliberate or unwitting effort to deflate asset prices. ${ }^{2}$ When the Fed did begin to ease in early 2001, these critics urged

\footnotetext{
${ }^{1}$ See Miller, Weller and Zhang (1999), for example. The moral hazard that such a belief fostered was reinforced by the Fed's easing actions in fall 1998, due to their concern over the emerging market financial crisis - especially its manifestation in Russia's partial sovereign default. There was also a perception in the market that the risks to the U.S. financial system arising from the near failure of Long-Term Capital Management (LTCM) and other hedge funds had contributed to the Fed's willingness to ease.

2 Glassman and Hassett (2001) complete the circle, in effect faulting the Fed for a fixation on stock prices in missing the downturn. They suggest that the Fed should have interpreted the fall in stock prices in spring 2000 as a sign of slowing and should have eased earlier. So it is not the fixation that was a problem, in their view, but the Fed's interpretation of the market signal.
} 
more rapid and extensive easing to calm the equity markets. In April and May 2001, the Fed muddied the water further, justifying two 50 basis point cuts in the federal funds rate, in part, by the decline in equity prices and risk this posed for consumer spending.

This article examines whether there is an exploitable link between the Fed's main policy instrument, the federal funds rate, and stock prices, as captured by the price-earnings (PE) ratio. Second, it looks at whether such a link supports the hypotheses of advocates for a Fed response to stock price changes. The PE ratio (and its inverse, the earnings yield) is used here to assess empirical relationships and the study uses annual data to investigate low frequency long-run relationships. It begins with a brief discussion of the theoretical issues related to stock prices and Fed objectives. Section II highlights the important theoretical channel tying inflation to adverse stock price developments, a channel often ignored in theoretical discussions.

Section III addresses the simple observation that there is an inverse relationship between the PE ratio and the fed funds rate. This relationship is at the heart of expectations that the Fed could vary the fed funds rate to inversely affect stock prices. The argument here is that this correlation does not provide evidence for assessing whether the Fed can influence stock prices or is influenced by them. The inverse relationship occurs only because both stock prices and the fed funds rate are related to a third factor-inflation, not because they are related to each other. The fed funds rate is a nominal interest rate and it is the real fed funds rate that should be related to the equity yield and its inverse, 
the PE ratio. ${ }^{3}$ There is no correlation between the real fed funds rate and the PE ratio, however.

Since a lack of correlation could arise from the simultaneous determination of stock prices and the real fed funds rate, causality tests and time series analysis are used to assess whether there is evidence of an exploitable relationship. The causality results are presented in section IV. Bi-directional causality from the earnings yield to the real federal funds rate is indicated. However, the signs of the relationships are opposite to those that are expected by some Fed critics who expect that an increase in the fed funds rate will lower stock prices and advocate that a rise (fall) in stock prices should raise (lower) the fed funds rate. In addition, causality evidence does not support the Fed's ability to influence the real fed funds rate.

Time series evidence shows that both the correlation and causality results are part of the broad dynamic relationship between the real fed funds rate and stock prices. More importantly, it establishes that there is a long-run positive relationship of real yields,

\footnotetext{
${ }^{3}$ Enough readers of earlier versions of this article have been troubled by the claim that the PE ratio is a real variable to warrant immediate attention to the issue. First, the PE ratio is the ratio of two nominal measures, hence it is a relative return, not a nominal rate. For example, deflating both price and earnings by the price level to obtain real measures leaves the ratio unchanged. More important, consider a simple dividend discount model of asset valuation where, for simplicity, it is assumed that the pay-out ratio is one, and real earnings are expected to remain constant. The value of an equity claim $(\mathrm{P})$ given nominal earnings is $E /(i-\pi)$, where $i$ is the required nominal return on equity and $\pi$ is the expected rate of inflation and earnings growth. Thus the PE ratio is the inverse of the real rate $r=(i-\pi)$ used to discount future earnings. The presence of dividends, an equity premium or growth of earnings does not alter the generality of these results. Inflation affects the PE ratio, then, only if real earnings, real growth, or the required real rate of interest used to discount earnings are affected by inflation.
} 
including the real fed funds rate and equity yield, which implies the expected inverse market relationship between the real fed funds rate and stock prices. However, the shortrun dynamics show that an increase in the real fed funds rate has no initial effect on stock prices, hence the absence of a contemporaneous correlation. An increase in the real fed funds rate, after a lag, will raise stock prices. Third, a positive shock to stock prices leads to a fall in the real fed funds rate according to the causality tests and this is reinforced by the error correction process and the long-run equilibrium relationship found in the time series analysis. Most importantly, the time series evidence indicates a long-run equilibrium relationship between stock prices and inflation. This relationship clarifies the role in inflation in the explanation for why a rise in the fed funds rate raises stock prices and conversely why a rise in stock prices leads to a fall in the fed funds rate. It also clarifies how the Fed can influence the real fed funds rate in the short run, but has no effect on the real fed funds rate or the ability of the Fed to influence stock prices in the long run.

Section V examines whether there is evidence that the Fed has reacted to increase in stock prices by raising the fed funds rate, as proponents of a reaction now advocate. Controlling for inflation and gross domestic product (GDP) gap in an estimate of the Taylor Rule, there is a significant negative relationship between stock prices and the nominal fed funds rate. When stock prices increase and there is a related decline in current and future inflation, the Fed systematically lowers the fed funds rate, and conversely for stock price declines. Since stock price moves are negatively related to inflation, dynamic relationships are opposite to conventional expectations. While the Fed 
has not, and apparently should not target stock prices, past performance in setting the fed funds rate at least reflected the correct relation: higher stock prices are an indicator of lower future inflation and support a lower fed funds rate.

Section VI provides a summary of the results and the implications. The conclusions can be briefly, if perhaps over-simplistically, anticipated. Policy actions that raise the fed funds rate to lower future inflation will, if successful, also raise stock prices. To react to the stock price rise by further tightening would destabilize the achievement of inflation and/or output goals. Second, other factors such as changes in tax policy or technology that could boost the rate of return to capital and thereby raise stock prices also lower future prices, other things equal. To tighten monetary policy in the face of favorable inflation developments would destabilize efforts to foster growth and maintain price stability. It is well known that adding new targets for policy-makers without increasing the number of instruments creates new trade-offs and compromises the effectiveness of policy. ${ }^{4}$ In this case, the problem would be worse because advocates of a stock price response propose targeting increasing stock prices as a source of higher future inflation, when in fact higher stock prices are typically an indicator of forces that are slowing inflation.

\section{The Theoretical Issues}

The central theoretical issue in this article is the relationship of stock prices to inflation. Proponents of a Fed reaction have in mind models in which a rise in stock prices boost wealth and thereby create a wealth effect raising consumption. The presence of this

\footnotetext{
${ }^{4}$ Bullard and Schaling (2002) provide a useful review of this problem and provide some evidence based on a theoretical investigation of adding a stock price objective to a Taylor Rule.
} 
wealth effect and of its strength are the subjects of a growing literature that goes beyond this paper. A second literature concerns the effect of inflation on stock prices. With neutrality of money, the conclusion of that literature is that inflation does not affect stock prices. Yet, as Bakshi and Chen (1996) note, a negative correlation between stock prices and inflation is one of the most commonly accepted empirical facts in financial economics. ${ }^{5}$ There is a theoretical literature that explains this correlation as arising from the non-neutrality of the tax system, though Bakshi and Chen ignore such arguments. ${ }^{6}$ Higher inflation boosts effective tax rates, lowering real after-tax returns on investment and thereby lowering stock prices. Similarly, lower stock prices affect the real cost of capital, investment, output and prices. These two channels are expected to dictate the relationship between monetary policy and stock prices and between stock prices and the objectives of the Fed. Whether there is a wealth effect is not the issue, so long as it is relatively weak, and that is the alternative hypothesis here. The federal funds rate, like other nominal rates, includes an inflation premium. If stock prices are inversely related to inflation, then there will be an inverse relationship between stock prices or the PE ratio and nominal fed funds rate, even if there were no relationship between the real fed funds rate and stock prices.

\footnotetext{
${ }^{5}$ Sharpe (2002) provides recent evidence using quarterly data from 1983 through I/2001 and Tatom (2002) also finds such a significant negative relationship using monthly data from July, 1954 through January, 2001.

${ }^{6}$ In their extensive review of the literature, the negative correlation of stock prices and inflation arises from pro-cyclical real interest rates, and hence counter-cyclical stock prices, along with pro-cyclical inflation. None of the models they review are based on non-neutralities arising through the tax system.
} 
The theoretical basis of the inverse relation of stock prices and inflation is the nonneutrality of the tax system for income from capital. For example, the taxation of corporate income based on income measures that use historical cost depreciation is one possible reason for an adverse effect of inflation on equity prices. Inflation raises the future replacement cost of capital, but not future cost for tax purposes. As a result, future earnings are overstated and this will boost taxes. Equity prices discount higher future taxes resulting in lower equity prices relative to current earnings. ${ }^{7}$ Thus, higher future prices will raise measured earnings and lower economic earnings via the tax effect. Both factors will lower the price-earnings ratio. In an earnings-discount model, a rise in inflation will raise the observed equity premium (due to the income measurement error and to a rise in the true equity premium). Second, as Barro (1996) and others have explained, higher inflation lowers true earnings growth because it raises the cost of capital, which lowers the optimal capital-labor ratio, slowing capital formation and income growth. These two effects will lower the PE ratio.

Hess and Lee (1999) argue that the relationship between stock prices and inflation depends on the source of inflation. In their view, aggregate demand shocks can boost inflation and stock prices but are neutral in their long-run effects on output and stock prices. In contrast, adverse supply shocks, which slow output and raise prices, in contrast, lower the return to capital and thereby lower stock prices, inducing a negative

\footnotetext{
${ }^{7}$ See Feldstein (1980) or Tatom and Turley (1976), for example. Fama (1981) suggests that the negative correlation between inflation and stock prices arises from supply shocks, while Modigliani and Cohn argue that inflation should raise stock prices. Other studies indicate that inflation reduces real economic growth. See Barro, (1996) for example. If capital income before taxes is a constant share of GDP, then corporate earnings growth is reduced by inflation as well.
} 
correlation between stock prices and inflation. Their model, following Bakshi and Chen, does not allow for non-neutrality of monetary growth or tax distortions that are a function of the price level or inflation. They find that demand-induced inflation raises stock prices, but they fail to point out that this effect is more than offset within two quarters. Thus both demand and supply shocks give rise to a reduction in stock prices in their work, though they focus on an initial effect, which appears to differ for the two sources. This distinction is not pursued here because there is no theoretical or empirical basis for a concern for this difference in the current context. ${ }^{8}$

\section{Stock Prices and the Federal Funds Rate: The Inflation Connection}

A basic problem for assessing the link between the federal funds rate and stock prices is their simultaneous determination. Consider the arguments of proponents of taking stock prices into account in setting policy. In their view, markets react to a federal funds rate hike by reducing stock prices, so there is a negative expected correlation between the federal funds rate and stock prices (called a market response, or reaction, below). On the other hand, they propose that the Fed raise rates when stock prices rise excessively, imparting a positive correlation between the two measures (called a Fed response or reaction below). Thus, either correlation could be observable. If one assumes the Fed does not currently react to stock prices and that markets do react to changes in the fed

\footnotetext{
${ }^{8}$ Tatom (2002) explicitly tests whether a long run equilibrium, or cointegrating, relationship found in monthly data for inflation and the earnings yield, the same as below, differs depending on the source of inflation and rejects the hypothesis that it is different. Specifically, inflation that is not systematically related to energy price shocks has the same negative effect on stock prices as does energy-price-shockbased inflation.
} 
funds rate, then the correlation between the two measures is expected to be negative. ${ }^{9}$

Another important question is how to measure the stock price to which the Fed may react or that is influenced by Fed activity. The choice here is to use the PE ratio for the S\&P 500, a broad index typically used to capture movements in aggregate stock prices. ${ }^{10}$ The PE ratio is based on an average of quarterly data, which are the endof-quarter stock price relative to the past four quarters' earnings. Thus, earnings are largely predetermined and movements in the yield reflect the change in stock prices. This is the main reason researchers use it as a measure of stock prices. The earnings yield, the inverse of the PE-ratio, also is more readily comparable to other yields. It is movements in stock prices relative to earnings that are of interest in assessing price movements that are of concern to investors or to policy-makers. There is also a strong negative correlation between annual changes in the S\&P stock price index (logarithm of average of daily figures) and annual changes in the earnings yield (-0.74). The discussion below concentrates on the use of the earnings yield, though differences in key results using stock prices are indicated. Figure 1 shows the nominal federal funds rate and the

\footnotetext{
${ }^{9}$ Rigoban and Sack (2001) focus on this problem and provide a useful way of dealing with it based on the heteroskedasticity of shocks to stock prices and the three-month Treasury bill rate. They find a positive correlation between stock prices and the three-month Treasury bill rate and interpret this as due to a Fed reaction. One study of the effect of monetary policy on stock returns, Booth and Booth (1997), shows that returns on stocks are inversely related to monetary policy variables, especially the fed funds rate, even controlling for business condition proxies. Their results hold for both expansions and contractions, contrary to the finding of Jensen et al. (1996), who find such an effect for contractions only when using the discount rate as the policy variable. Earlier studies argued that monetary policy affected stock returns by affecting business condition variables, such as dividend spreads, default spreads and term spreads. See Fama and French (1989) for the classic statement of this argument.

${ }^{10}$ Shen (2000) uses the S\&P PE ratio as a measure of stock prices and its inverse as the earnings yield. Shen follows Campbell and Shiller (1998), in this regard, and is primarily interested in the predictive content of the PE ratio for future stock prices. Interestingly, Shen, following his own work and others, advocates the use of the earnings yield less a nominal interest rate measure as a predictor of future stock prices. The arguments below apply to this mix of a real yield and nominal interest rate, in particular, the sensitivity of both to inflation.
} 
earnings yield. The real federal funds rate (based on the consumer price index) is also shown. ${ }^{11}$ The nominal federal funds rate appears to be positively related to the earnings yield, so that a higher federal funds rate is associated with lower stock prices. The simple correlation coefficient for the two measures (Table 1) is positive and statistically significant at a conventional 5 percent level. The first-differences in the federal funds rate and in the earnings yield are also significantly correlated (Table 2).

There is a clear pattern to the fed funds rate and earnings yield in Figure 1: both measures generally rose until the early 1980s and then generally fell.

\section{Figure 1}

The Earnings Yield Is Correlated With the Federal Funds Rate

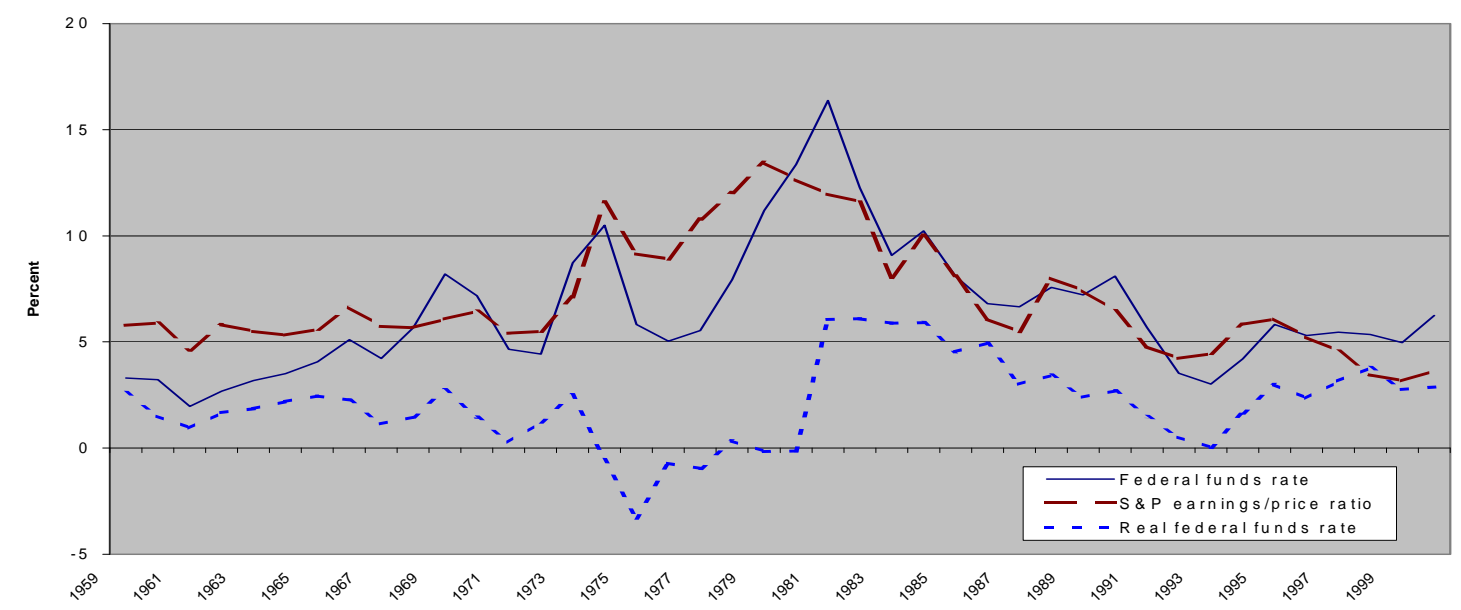

\footnotetext{
${ }^{11}$ The data used are from the U.S. Council of Economic Advisers (2001) and their monthly publication, Selected Economic Indicators. The federal funds rate is the annual average of monthly averages of daily figures. The CPI is also the average of monthly data, so the real fed funds rate is the annual average fed funds rate less annual inflation. The ex post real rate assumed to be a reliable indicator of the ex ante rate. A test of whether actual inflation is a suitable measure for anticipated inflation was conducted using the biannual Livingston Survey forecasts of inflation and comparable year ahead measures of actual inflation from 1959 through 2000. An F-test of the joint hypothesis for whether the Livingston forecast is unbiased and has a unit coefficient in forecasting actual inflation is 0.32, which is not significant; the five-percent critical value $(2,83)$ is 3.11 . The individual t-statistics for the components of this hypothesis are each less than one.
} 
This corresponds to the pattern of inflation, rising from 1959 to the early 1980s, then falling. The individual cases where the two series rose the most, contributing to the appearance of a positive relationship, are periods when inflation rose sharply, especially 1974 and 1980-81. Significant correlation coefficients indicate that inflation has a positive relationship with the nominal fed funds rate and a negative relationship with stock prices.

Table 1

Correlation Coefficients (Levels) (1959-2000)

\begin{tabular}{|l|c|c|c|c|}
\hline & $\begin{array}{l}\text { Federal funds } \\
\text { rate }\end{array}$ & $\begin{array}{l}\text { Earnings- } \\
\text { price ratio } \\
\text { (S\&P 500) }\end{array}$ & $\begin{array}{l}\text { Real federal } \\
\text { funds rate }\end{array}$ & $\begin{array}{l}\text { Inflation rate } \\
\text { (CPI) }\end{array}$ \\
\hline $\begin{array}{l}\text { Federal funds } \\
\text { rate }\end{array}$ & 1.0 & 0.78 & 0.35 & 0.78 \\
\hline $\begin{array}{l}\text { Earnings- } \\
\text { price ratio } \\
\text { (S\&P 500) }\end{array}$ & & 1.0 & $-\mathbf{0 . 0 7}$ & 0.84 \\
\hline $\begin{array}{l}\text { Real federal } \\
\text { funds rate }\end{array}$ & & & & -0.30 \\
\hline $\begin{array}{l}\text { Inflation rate } \\
\text { (CPI) }\end{array}$ & & & 1.0 & 1.0 \\
\hline
\end{tabular}

Critical value (5 percent): 0.31; insignificant correlation in bold.

The correlation coefficients for the first-differences (Table 2) show the same significant relationships. ${ }^{12}$ This suggests that the relationship between the fed funds rate and the PE ratio arises from a common third factor, inflation. The role of inflation in producing the correlation between the federal funds rate and the earnings yield is reinforced by the fact that the correlation between the real federal funds rate and stock prices is near zero, not significantly positive $(-0.07)$.

\footnotetext{
${ }^{12}$ Like the earnings yield, there is no significant correlation between stock price changes with changes in the nominal or real federal funds rate, the manufacturing capacity utilization rate or the GDP gap.
} 
Table 2

Correlation coefficients for first-differences

(1960-2000)

\begin{tabular}{|l|c|c|c|c|}
\hline & $\begin{array}{l}\text { Federal funds } \\
\text { rate }\end{array}$ & $\begin{array}{l}\text { Earnings-price } \\
\text { ratio (S\&P } \\
\text { 500) }\end{array}$ & $\begin{array}{l}\text { Real federal } \\
\text { funds rate }\end{array}$ & $\begin{array}{l}\text { Inflation rate } \\
\text { (CPI) }\end{array}$ \\
\hline $\begin{array}{l}\text { Federal funds } \\
\text { rate }\end{array}$ & 1.0 & 0.63 & 0.48 & 0.67 \\
\hline $\begin{array}{l}\text { Earnings-price } \\
\text { ratio (S\&P } \\
\mathbf{5 0 0 )}\end{array}$ & 1.0 & $\mathbf{0 . 0 5}$ & 0.64 \\
\hline $\begin{array}{l}\text { Real federal } \\
\text { funds rate }\end{array}$ & & & 1.0 & -0.33 \\
\hline $\begin{array}{l}\text { Inflation rate } \\
\text { (CPI) }\end{array}$ & & & & 1.0 \\
\hline
\end{tabular}

Critical value (5 percent): 0.31; insignificant correlation in bold

The correlation between changes in the real federal funds rate and the earnings yield is also essentially zero (0.05). It appears that the Fed has had no influence on asset prices for the past 40 years, at least on a contemporaneous, or within the year, basis.

The positive relationship for the fed funds rate and the earnings yield in Figure 1 apparently arises from the fact that during periods when inflation was higher, nominal interest rates were higher and stock prices were lower. Controlling for inflation, changes in the federal funds rate have had no effect on stock prices.

There are two other points about the inflation correlation coefficients worth noting. First, the real federal funds rate is only marginally related to inflation at best, according to these simple statistics. A negative correlation might be expected to result from the construction of the real rate or from a policy-related rise (fall) in the real federal funds rate that induces a simultaneous reduction (rise) in inflation. But the real federal funds rate, like many other real interest rate measures, may simply be unrelated to nominal developments 
such as inflation, a strong form of the Fisher effect in which money growth and inflation are neutral. Second, there is a strong and significant positive relation of the earnings yield and inflation. The earnings yield is a key component of the cost of capital. It is likely to have a negative correlation with investment and output resulting in a positive relationship to prices or inflation. The correlation coefficients for the levels of the earnings yield and inflation and for first-differences in each are 0.84 and 0.64 , respectively. ${ }^{13}$

The appropriate comparison for assessing the influence of monetary policy on equity prices, especially the earnings yield, is to look at the real federal funds rate, since the earnings yield on equities is a real yield. Tables 1 and 2 also provide the correlation of the real federal funds rate and the earnings yield. The correlation coefficients suggest that the Fed would not be capable of influencing equity prices by altering the real federal funds rate, should they want to, though this evidence may be weak to the extent that the Fed has not tried to influence stock prices. ${ }^{14}$

\footnotetext{
${ }^{13}$ There have been few studies of the effects of asset prices on inflation. Stock and Watson (2001) review the literature and provide their own evidence indicating that the effects of asset prices on inflation are not stable across time periods and countries. The time series results below are not sensitive to time period, however, at least within the range of the data available here. Stock and Watson's review includes tests for the nominal and real stock price and the dividend yield. They do not examine any long-term interest rate effect. Instead they examine potential effects of short-term rates or spreads on inflation.

${ }^{14}$ To check for significant positive leading or lagging relationships between the real federal funds rate and the earnings yield, one and two period leads and lags of each measure were added to the correlation matrix. The results reveal a significant negative correlation between the lagged real federal funds rate and the oneperiod-ahead earnings yield. This suggests that a higher real federal funds rate in the current period will raise stock prices two years later, not the result expected by proponents using monetary policy to stabilize the stock market. All other lead/lags had insignificant correlation coefficients. The same pattern is revealed in the causality tests below, but controlling for inflation, it becomes insignificant, suggesting that that higher fed funds rate lead to lower fed funds rates only because they lower inflation.
} 


\section{Causality Tests}

To test for causality, Granger causality tests for all four variables in Tables 1 and 2 were conducted for lags up to five years. ${ }^{15}$ With only one lag, the absence of causality cannot be rejected for any pair of variables. Adding two or three lags resulted in increasing numbers of rejections of the absence of causality, but the results with four or five lags were the same as with three lags. The first three columns of Table 3 show the causality test results for each pair using three lags. The last three columns in the table report the results of more detailed examination of the significant lagged independent variables and the sign of their effects. For the Granger-causality column, only significant lagged dependent variables are included and these are found from searches of the auto-regressive properties of each dependent variable. The number of lags is indicated in the first entry for each equation in the last column. The Granger causality equations are also estimated including current and past inflation terms to control for the influence of inflation in accounting for the causality. These results are reported in the penultimate column and the number of significant inflation lags included is shown in the last column (from zero to the number indicated).

Table 3 shows that there is bi-directional causality between the earnings yield and both the federal funds rate and the real federal funds rate. Each of the latter two variables causes inflation, according to the evidence. Before examining the causal relationships in more detail, it is important to note the evidence on the absence of causality. First, the evidence shows that the Fed cannot control the real federal funds rate, the primary

\footnotetext{
${ }^{15}$ For asset prices, it is only innovations in policy or economic performance that should matter, and then only contemporaneously. The vector-error-correction evidence below may be more pertinent for assessing the effects of shocks in one measure on the other.
} 
channel for the influence of monetary policy, at least in a fed funds rate-targeting

framework. The causality tests cannot reject the absence of causality either from the fed

funds rate to the real fed funds rate or vice versa. ${ }^{16}$ Second, the evidence cannot reject the absence of causality from inflation to the earnings yield or the reverse; movements in stock prices do not cause inflation and stock prices do not affect inflation, in a Grangercausal sense at least. There is a relationship between inflation and stock prices indicated in the table, however, and this relationship is discussed below. Third, the absence of causality from the nominal or real federal funds rate to inflation cannot be rejected, but as noted, the evidence supports the reverse direction of causality. Thus it would appear that inflation does not cause a reaction by the Fed, but movements in the nominal (and real) fed funds rate cause inflation.

A closer look at the causality tests can reduce the incredulity these results may create. In particular, the only significant lag on the fed funds rate is the second lag and the sign of its effect on inflation is negative. The evidence suggests that inflation does not cause the Fed to change the fed funds rate, but it is consistent with increases in the fed funds rate reducing inflation with a two-year lag. ${ }^{17}$

\footnotetext{
${ }^{16}$ In tests that add current and lagged inflation terms to a Granger test equation, reported in the last two columns of Table 3, a rise in the fed funds rate is shown to cause a rise in the real fed funds rate, but the reverse is not the case.

${ }^{17}$ Tests that add current inflation to the test equations further clarify the relationship of inflation and the fed funds rate. The absence of causality from inflation to the nominal fed funds rate does not hold up when the current period inflation rate is included in the estimate. In the reverse case, however, there is no positive effect of inflation on the real fed funds rate even when the current inflation rate is included. Taken together, these results suggest that most of the variation in the federal funds rate reflects a reaction to inflation aimed at maintaining the real fed funds rate, not changing it or allowing it to be changed by inflation.
} 
Table 3

Causality Tests

\begin{tabular}{|c|c|c|c|c|c|}
\hline \multicolumn{2}{|c|}{$\begin{array}{l}\text { Hypothesis: Variable A } \\
\text { does not cause variable B }\end{array}$} & \multirow{2}{*}{ 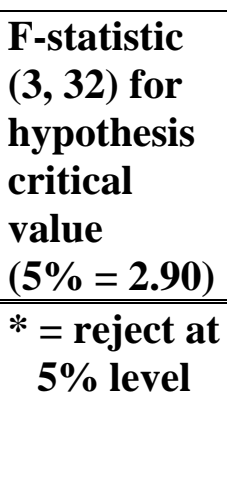 } & \multicolumn{3}{|c|}{$\begin{array}{l}\text { Significant lag(s)/sum effect } \\
\text { (t-statistic) }\end{array}$} \\
\hline Variable $A$ & Variable B & & $\begin{array}{l}\text { Granger } \\
\text { causality }\end{array}$ & $\begin{array}{l}\text { Including } \\
\text { inflation }\end{array}$ & $\begin{array}{c}\text { Lag } \\
\text { structure } \\
\text { (variable B, } \\
\text { inflation) }\end{array}$ \\
\hline $\begin{array}{l}\text { Federal funds } \\
\text { rate }\end{array}$ & Earnings yield & $8.37 *$ & $\begin{array}{c}2(-), 3(+) / \\
-0.192 \\
(-2.41)\end{array}$ & $\begin{array}{c}2(-), 3(+) / \\
-0.145 \\
(-1.67)\end{array}$ & $(1,2)$ \\
\hline Earnings yield & $\begin{array}{l}\text { Federal funds } \\
\text { rate }\end{array}$ & $5.13 *$ & $\begin{array}{c}2(+) \\
0.546 \\
(3.39) \\
\end{array}$ & $\begin{array}{c}2(+) \\
0.378 \\
(3.16) \\
\end{array}$ & $(1,1)$ \\
\hline $\begin{array}{l}\text { Real fed funds } \\
\text { rate }\end{array}$ & Earnings yield & $3.24 *$ & $\begin{array}{c}2(-) \\
-0.314 \\
(-3.03) \\
\end{array}$ & $\begin{array}{c}\text { NA } \\
-0.164 \\
(-1.67) \\
\end{array}$ & $(1,0)$ \\
\hline Earnings yield & $\begin{array}{l}\text { Real fed funds } \\
\text { rate }\end{array}$ & $3.71^{*}$ & $\begin{array}{c}1(-), 2(+) \\
0.138 \\
(1.74)\end{array}$ & $\begin{array}{c}2(+) \\
0.328 \\
(3.48)\end{array}$ & $(1,1)$ \\
\hline$\overline{\text { Inflation }}$ & Earnings yield & 2.08 & NA & $\begin{array}{c}0(+), 1(-), 2(+) \\
0.353 \\
((3.15) \\
\end{array}$ & (1.2) \\
\hline Earnings yield & Inflation & 0.28 & NA & SAME & (3) \\
\hline $\begin{array}{l}\text { Real fed funds } \\
\text { rate }\end{array}$ & $\begin{array}{l}\text { Federal funds } \\
\text { rate }\end{array}$ & 1.70 & NA & NA & (1.2) \\
\hline $\begin{array}{l}\text { Federal funds } \\
\text { rate }\end{array}$ & $\begin{array}{l}\text { Real fed funds } \\
\text { rate }\end{array}$ & 1.34 & NA & $\begin{array}{c}1(+) \\
0.713 \\
(6.37) \\
\end{array}$ & $(0.1)$ \\
\hline Inflation & $\begin{array}{l}\text { Federal funds } \\
\text { rate }\end{array}$ & 1.70 & NA & $\begin{array}{c}0(+), 1(-) \\
0.291 \\
(2.58) \\
\end{array}$ & $(1,1)$ \\
\hline $\begin{array}{l}\text { Federal funds } \\
\text { rate }\end{array}$ & Inflation & $3.53 *$ & $\begin{array}{c}2(-) \\
-0.322 \\
(-2.90) \\
\end{array}$ & SAME & $(3, N A)$ \\
\hline Inflation & $\begin{array}{l}\text { Real fed funds } \\
\text { rate }\end{array}$ & 1.34 & NA & $\begin{array}{c}0(+) .1(-) \\
0.005 \\
(0.06)\end{array}$ & $(1, \mathrm{NA})$ \\
\hline $\begin{array}{l}\text { Real fed funds } \\
\text { rate }\end{array}$ & Inflation & $3.53^{*}$ & $\begin{array}{c}2(-) \\
-0.322 \\
(-2.90) \\
\end{array}$ & SAME & (3,NA) \\
\hline
\end{tabular}


Such an effect of the fed funds rate (nominal or real) is also observed for stock prices. A rise in the fed funds rate will raise stock prices and do so two years later, just as the effect reducing inflation is realized. The test for the hypothesis that the fed funds rate causes the earnings yield indicates that there is a statistically significant causal effect two years later lowering the earnings yield, or raising stock prices. For the nominal fed funds rate, some of this effect is reversed three years later, but the overall effect of a higher fed funds rate raising stock prices remains after three years.

The last column in Table 3 clarifies the importance of inflation in accounting for this result. When current and past values of inflation are added to the test equations, the effect of the fed funds rate on the earnings yield is not significant. The real fed funds rate two years earlier now has no statistically significant effect on the stock prices, once inflation is taken into account. Similarly the overall effect of a rise in the nominal fed funds rate in raising stock prices two years later, then lowering them in the third year, becomes insignificant after three years, once inflation is taken into account. ${ }^{18}$

Thus, while there is no evidence that stock prices and inflation are causally related, ignoring current inflation, factors that causally affect inflation, in this case the fed funds rate, also affect stock prices. When inflation is included in the test equation, there is no additional influence of the fed funds rate on stock prices. On the other hand, inflation is found to cause stock prices when current inflation is added to the right hand side in the Granger causality test equation; inflation has an initial and overall negative effect on

\footnotetext{
${ }^{18}$ Each lag remains significant, however, with the second lag having a coefficient of $-0.379(\mathrm{t}=-2.83)$ and the third lag having a coefficient of $0.234(\mathrm{t}=2.14)$. As noted in Table 3 , the sum is not different from zero once inflation is taken into account.
} 
stock prices. In the case of the transitory effect of the nominal fed funds rate on stock prices, the effect is positive, contrary to the expectations of proponents of a Fed reaction to stock price increases.

Stock prices also cause the fed funds rate according to the causality tests. The causality tests in the second and fourth rows of Table 3 show that a rise in stock prices (fall in the earnings-yield) will be followed two years later by a significant fall in the fed funds rate. For the real fed funds rate, the causality result is slightly different, with an initial rise in the fed funds rate a year later being followed by an offsetting fall in the real fed funds rate in the second year. When the inflation rates are added to the Granger causality tests, the results are more uniform and indicate that only the effect two years later is statistically significant and that higher stock prices lead to lower real and nominal fed funds rate two years later. This is strongly at odds with the direction of causality advocated by proponents of a Fed reaction. Thus, the evidence on existing relationships contradicts both of the conventional hypotheses advocated by the proponents of a Fed reaction to stock prices. A higher fed funds rate raises stock prices, though this effect arises completely from the effects of the funds rate on inflation. In turn, a higher stock price leads to a fall in the fed funds rate and this effect is significant, whether or not inflation is included in the test equation. ${ }^{19}$ Thus the causal link tying a rise in stock prices to a subsequent fall in the real fed funds rate arises from a future fall in inflation.

\footnotetext{
${ }^{19}$ This effect can also be shown to arise from inflation. When two significant leading values of inflation are included in the estimate of the fed funds rate, along with the lagged fed funds rate and the second lag of the earnings-yield, the coefficient on the earnings yield is still positive (0.168), but it is not statistically significant $(\mathrm{t}=1.37)$.
} 


\section{Time Series Evidence}

The correlation results provide an overview of the issues and the causality tests suggest a link from movements in stock prices to the real fed funds rate, but it is possible to test the relationship of the federal funds rate and equity prices more fully using time series analysis. First, it is necessary to identify the time series behavior of each series. All four measures in Table 1 have a unit root according to augmented Dickey-Fuller tests (ADF). The ADF statistics for the federal funds rate, earnings yield, real federal funds rate and inflation rate (number of included significant lagged dependent variables is given in parenthesis) are: $-2.79(1),-1.53(0),-2.49(0)$ and -1.90 (2), respectively. The critical value (5 percent) is -2.94 . The unit root hypothesis for the federal funds rate is not rejected at a 10 percent significance level where the critical value is -2.61 , but this level of significance is typically considered too weak.

A unit root is rejected for all the first-differences of the series. The ADF statistics are (lagged changes in parentheses): -5.94 (1), -6.56 (0), -6.57 (0) and -6.45 (1), for the federal funds rate, earnings yield, real federal funds rate and inflation, respectively; the critical value (5\%) equals -2.94 . Thus all four series are random walks and the measures are potentially cointegrated. Cointegration could provide very strong evidence favoring a causal link between the real federal funds rate and stock prices. ${ }^{20}$

\footnotetext{
${ }^{20}$ Persistence could account for the failure to reject a unit root. Inclusion of a significant moving-average error process in the estimations indicates strong persistence. For each of the four variables here, adding an MA (1) term is significant; the t-statistics are larger than 3.70 and the t-statistic on the relevant lagged level for the ADF test is also relatively large, suggesting that the variables are stationary. In Tatom (2002), monthly data for 1954 to 2001 finds that only the real fed funds rate is stationary. If in fact the data here are I(0) then the long-run relationships, and their interpretation as such, are not affected, but the parameter estimates would not have the super-consistency property that parameters in long-run relationships between I(1) series would have.
} 
Johansen's method was used to examine whether bivariate pairs of the earnings yield, nominal federal funds rate, real federal funds rate and inflation are cointegrated. The Schwartz criterion indicates in each case that for five alternative specifications of trends in the data and intercepts in the potential cointegrating equations (CE), the best specification is that without an intercept and trend. The various specifications are: no data trend, with or without an intercept in the CEs, a linear trend in the data with an intercept in the CE and with or without a trend in the CE, and a quadratic trend in the data with both an intercept and a trend in the CE. The best specification—no trend or intercept in the $\mathrm{CE}$ —obtains for the model with specifications of the lagged differences in the variables ranging from one to four lags.

Table 4 shows trace test statistics for cointegration for the optimal lag structure found from Likelihood Ratio tests. The optimal lags were found assuming one potential cointegrating equation. No specification outperformed a "no-trend, no-intercept" specification. Only two pairs of variables exhibit a significant CE, the earnings yield and the real federal funds rate and the earnings yield and inflation. The trace test statistic for two CE in these two-equation models are 0.64 and 0.58 , respectfully, indicating that there is only one CE in each case (critical value is 3.84). The nominal fed funds rate is unrelated to any measure in the long run, including the real federal funds rate. 


\section{Table 4}

\section{Cointegration tests}

\begin{tabular}{|l|l|l|}
\hline Variables & Lag Length & Trace Statistic* \\
\hline E_P and FF & 2 & 9.83 \\
\hline E_P and RFF & 3 & $22.40^{*}$ \\
\hline E_P and PDOT & 1 & $16.44^{*}$ \\
\hline FF and RFF & 2 & 6.10 \\
\hline FF and PDOT & 2 & 6.10 \\
\hline RFF and PDOT & 2 & 6.10 \\
\hline
\end{tabular}

*Critical Value: 12.52 (5\%), 16.31 (1\%)

The significant vector error correction (VEC) models are indicated in Table $5 .{ }^{21}$ The significant cointegrating vectors are indicated in the top panel for each model. The first

CE indicates a long-run CE with a positive relation between the real yield and the real fed

funds rate. For a long-run equilibrium value of the real fed funds rate of two percent, the long-run equilibrium earnings yield is about eight or the equilibrium PE-ratio is 12.5.

The long-run relation provides strong support for the existence of the market relationship in which a rise in stock prices reduces the real fed funds rate, and conversely a rise in the fed funds rate lowers the earnings yield.

\footnotetext{
${ }^{21}$ To check the robustness of the results for the earnings yield, tests of whether the log of the S\&P price index is cointegrated with the nominal or real fed funds rate were conducted. The tests indicate that, for both variables, the optimal VEC specification has one lag and the trace test indicates significant cointegration. The optimal specifications have an intercept and no trend in the CE. However, the t-statistic for the CE coefficient on either fed funds rate measure is not statistically significant (1.43 and 1.81, respectively). In addition, the impulse response functions show that a positive shock to the fed funds rate has no effect on the stock price until two years later, then a negative effect for years two and three and subsequently the effect turns increasingly positive. A positive shock to the real fed funds rate also has no effect on the stock price until year three, when it begins to be increasingly positive as well. This is the same result as shown in the top panel of Figure 2 for the earnings yield below, where the positive stock price (negative earnings yield) effect appears in year three and beyond. The stock price measure is poorly conditioned and should be measured in real terms or relative to earnings to control for the strong positive trend, though unit root tests reject a trend and a trend is not indicated in the specification tests for the CE. Nonetheless, the results support those in the test and the use of the earnings yield as an inverse measure of the stock price.
} 
The second CE in Table 5 indicates that there is a long-run negative relation between inflation and stock prices, as indicated in the correlation analysis and as hypothesized. Together with the first CE, there is an implied third long-run relation between the real fed funds rate and inflation. Specifically, each percentage point of inflation is associated with a 38 basis point rise in the real fed funds rate. This is at odds with the assumed neutrality of real rates with respect to inflation and with the marginally significant negative contemporaneous correlation for first-differences of the two measures (Table 2). Presumably it reflects a positive effect of inflation on the real fed funds rate because of heightened policy risk or inflation uncertainty. ${ }^{22}$ The error correction (EC) term is indicated as the first term in the lower panel for each equation. Each EC equation includes lags of the dependent variables to capture the dynamics in the relationship. The standard error is indicated below each coefficient and the t-statistic is shown below the standard error. Statistically significant EC terms indicate significant causality. ${ }^{23}$ The significance of the EC term from the first CE in the earnings yield and real fed funds rate equations indicate that a positive shock to the earnings yield (fall in stock price) will cause a rise in the earnings yield (momentum) and in the real fed funds rate.

\footnotetext{
${ }^{22}$ This positive relationship is consistent with a significant positive relationship of the annual real eurocurrency yield and inflation in a cross section of 17 advanced economies over the 1973-99 period. Tatom (2000) finds that each percentage point rise in inflation raises the real rate by 25 basis points, not much different from the 38 basis points implied in Table 5. Sharpe (2002) also finds that inflation raises a measure of the expected real bond yield and by even more than here (0.75).

${ }^{23}$ This causal interpretation of a significant error correction term in a VEC model follows Engel and Granger (1987).
} 


\section{Table 5}

\section{Error Correction Models for the Earnings Yield, Real Fed Funds Rate and Inflation}

Standard errors \& t-statistics in parentheses

\begin{tabular}{|c|c|c|c|c|c|}
\hline Cointegrating Eq: & CointEq1 & & Cointegrating Eq: & CointEq2 & \\
\hline E_P(-1) & 1.00 & & E_P(-1) & 1.00 & \\
\hline $\operatorname{RFF}(-1)$ & $\begin{array}{c}-3.893 \\
(0.5054) \\
(-7.70) \\
\end{array}$ & & PDOT(-1) & $\begin{array}{c}-1.506 \\
(0.1148) \\
(-13.12) \\
\end{array}$ & \\
\hline Error Correction: & $\mathrm{D}\left(\mathrm{E} \_\mathrm{P}\right)$ & $\mathrm{D}$ (RFF) & Error Correction: & $\mathrm{D}\left(\mathrm{E} \_\mathrm{P}\right)$ & $\mathrm{D}(\mathrm{PDOT})$ \\
\hline CointEq1 & $\begin{array}{c}0.104 \\
(0.0403) \\
(2.59)\end{array}$ & $\begin{array}{c}0.133 \\
(0.0400) \\
(3.32)\end{array}$ & CointEq2 & $\begin{array}{c}0.016 \\
(0.0927) \\
(0.17)\end{array}$ & $\begin{array}{c}0.295 \\
(0.0983) \\
(3.00)\end{array}$ \\
\hline $\mathrm{D}\left(\mathrm{E} \_\mathrm{P}(-1)\right)$ & $\begin{array}{c}-0.269 \\
(0.1797) \\
(-1.50)\end{array}$ & $\begin{array}{c}-0.605 \\
(0.1784) \\
(-3.39)\end{array}$ & $\mathrm{D}\left(\mathrm{E} \_\mathrm{P}(-1)\right)$ & $\begin{array}{c}-0.150 \\
(0.2149) \\
(-0.70)\end{array}$ & $\begin{array}{c}-0.023 \\
(0.2277) \\
(-0.10)\end{array}$ \\
\hline $\mathrm{D}\left(\mathrm{E} \_\mathrm{P}(-2)\right)$ & $\begin{array}{c}-0.387 \\
(0.1952) \\
(-1.98)\end{array}$ & $\begin{array}{c}-0.092 \\
(0.1931) \\
(-0.47)\end{array}$ & & & \\
\hline$D\left(E \_P(-3)\right)$ & $\begin{array}{c}-0.484 \\
(0.1854) \\
(-2.61)\end{array}$ & $\begin{array}{c}-0.289 \\
(0.1841) \\
(-1.57)\end{array}$ & & & \\
\hline $\mathrm{D}(\mathrm{RFF}(-1))$ & $\begin{array}{c}0.390 \\
(0.171) \\
(2.28)\end{array}$ & $\begin{array}{c}0.258 \\
(0.1699) \\
(1.52)\end{array}$ & $\mathrm{D}(\mathrm{PDOT}(-1))$ & $\begin{array}{c}0.115 \\
(0.1828) \\
(0.63)\end{array}$ & $\begin{array}{c}0.448 \\
(0.1938) \\
(2.31)\end{array}$ \\
\hline $\mathrm{D}(\mathrm{RFF}(-2))$ & $\begin{array}{c}-0.205 \\
(0.1602) \\
(-1.28)\end{array}$ & $\begin{array}{c}0.032 \\
(0.1591) \\
(0.20)\end{array}$ & & & \\
\hline $\mathrm{D}(\mathrm{RFF}(-3))$ & $\begin{array}{c}0.079 \\
(0.1604) \\
(0.49) \\
\end{array}$ & $\begin{array}{c}0.090 \\
(0.1592) \\
(0.57) \\
\end{array}$ & & & \\
\hline Adj. R-squared & 0.203 & 0.294 & Adj. R-squared & -0.040 & 0.228 \\
\hline Sum sq. resids & 53.87953 & 53.09624 & Sum sq. resids & 82.7089 & 92.9919 \\
\hline S.E. equation & 1.3184 & 1.3087 & S.E. equation & 1.4951 & 1.5853 \\
\hline F-statistic & 2.57 & 3.57 & F-statistic & 0.24 & 6.75 \\
\hline Log likelihood & -60.5538 & -60.2755 & Log likelihood & -71.2865 & -73.6302 \\
\hline Akaike AIC & 3.5555 & 3.5408 & Akaike AIC & 3.7143 & 3.8315 \\
\hline Schwarz SC & 3.8571 & 3.8425 & Schwarz SC & 3.8410 & 3.9581 \\
\hline Mean dependent & -0.0574 & 0.031 & Mean dependent & -0.0565 & 0.0413 \\
\hline S.D. dependent & 1.4771 & 1.5579 & S.D. dependent & 1.4659 & 1.8039 \\
\hline
\end{tabular}


This significant EC term also indicates that a positive shock to the real fed funds rate will lower the earnings yield and reduce the real fed funds rate. The latter effect indicates significant error correction for the real fed funds rate. The significance of the EC term from the second CE in the inflation equation indicates that a positive shock to the earnings yield or fall in inflation will cause a rise in the earnings yield and a fall in inflation. There is significant error correction for inflation and a strong negative effect of stock prices on inflation. In particular, a positive shock to the earnings yield (a decline in stock prices) causes a rise in inflation.

It is important to note that causality only means a systematic time sequencing of developments. Thus, the evidence is consistent with increases in rationally expected inflation lowering stock prices before the inflation increase is observed. The result is also consistent with the notion that a rise in stock prices, which lowers the earnings yield and cost of capital, can permanently lower prices. Both the real federal funds rate and inflation exhibit error correction properties, but the earnings yield does not. The earnings yield (stock price) is exogenous with respect to inflation and exhibits momentum (a positive relation to its own past shocks).

The time series evidence on causal relationships between the real fed funds rate and the earnings yield (stock prices) reinforces the causality results in rejecting the conventional view. Table 6 provides a summary of these differences. The time series evidence shows a dominant long-run market response, but it is capable of reconciling the correlation and simple causality results as well. 
Table 6

Relationship of the Real Fed Funds Rate (RFF) and the Earnings Yield (E_P)

\begin{tabular}{|l|c|c|}
\hline & From RFF to E_P & From E_P to RFF \\
\hline Conventional Hypothesis & + & - \\
(Market Response) & (Proposed Fed Response) \\
\hline Correlation Result & 0 & 0 \\
\hline Causality Result & $-\left(-^{*}\right)^{* *}$ & $(+)^{* *}$ \\
\hline Time Series Evidence: & + & + \\
\hline Long-Run (CE) & - & + \\
\hline Error Correction Response & & \\
\hline
\end{tabular}

*Positive sum effect after two years is not significantly different from zero.

**Including current and lagged inflation terms in Granger-causality test equation

The time series results find a long-run equilibrium positive relationship between the earnings yield and real fed funds rate, consistent with the expectation of a positive link between real yields across the maturity spectrum and with the expected market response. However, the error correction terms in the VEC model show a bi-directional pattern that is precisely the opposite of that expected in the conventional view and identical to that found in the causality tests. The EC effect indicates that a rise in the real fed funds rate will raise stock prices and a rise in stock prices will lower the fed funds rate. Both reactions presumably arise because of the link between stock prices and inflation. When stock prices rise, inflation improves and the Fed apparently eases, while increases in the fed funds rate suggest lower subsequent inflation, inducing a subsequent rise in stock prices. Some clarification of the differences in Table 6 is possible using the impulseresponse function results below. 


\section{Implications of the Time Series Model for Shocks}

The VEC model can be used to illustrate some of the dynamic effects of shocks to the real federal funds rate, the earnings yield and inflation on the three variables. Figure 2 provides impulse-response patterns of the effects of shocks to each variable on the other measures. In the top left panel, the principal result is that a one-standard deviation rise in the real federal funds rate has no effect on the earnings yield for two years and a negative effect in year three and beyond. Over time, such a shock will lower the earnings yield by about 70 basis points. This is precisely the opposite of the effect expected by most analysts who advocate using the federal funds rate to stabilize the equity market!

However, the initial pattern supports the absence of a contemporaneous correlation for stock prices and the real fed funds rate. The bottom panel on the left shows that there is also a negative dynamic relation between the real funds rate and the earnings yield that indicates that a fall in stock prices can induce a fall in the real funds rate contemporaneously and one year later. This is the same as the dynamic effect expected by proponents of a Fed reaction and it is the same as the effect observed after one year in the simple causality results above (Table 3). There the effect is not statistically significant when inflation is taken into account, however; the only significant effect is a positive one that occurs with a two-year lag.

The error-correction term for the effect of a rise in the earnings yield on the real fed funds rate in the second column on the left in Table 4 also shows the positive causal link from a positive shock to the earnings yield to the real fed funds rate. Note that inflation has little or no effect on the real funds rate in the impulse response panel on top right of Figure 2, 
but a fall in stock price (rise in the earnings yield) has a large positive effect on inflation.

This response is also indicated in the long-run equilibrium relationship.

\section{Figure 2}

Impulse-Response Patterns for Shocks to the Error-Correction Model (Based on Table 5)
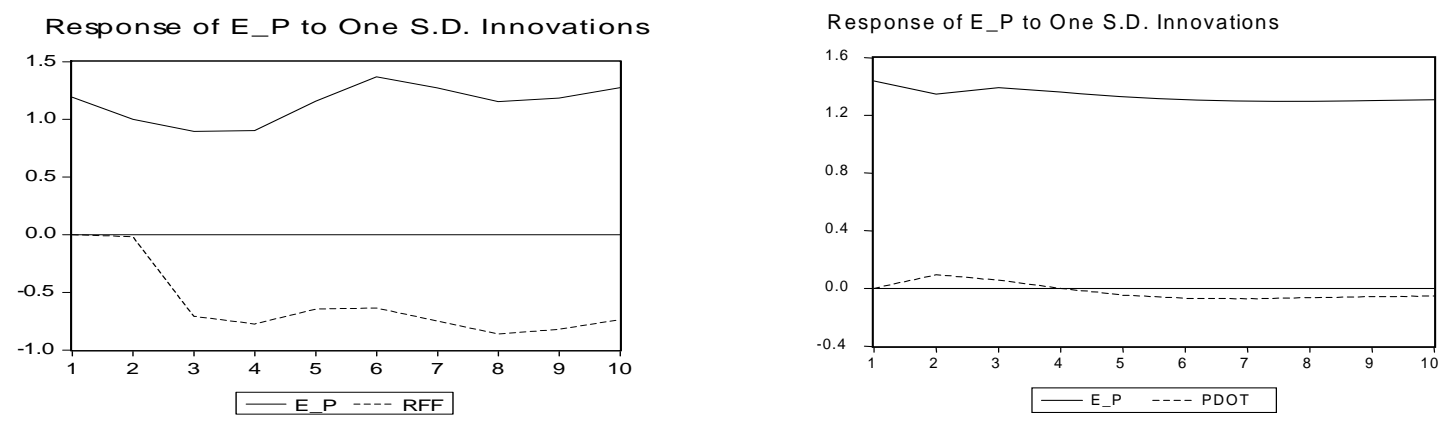

Response of RFF to One S.D. Innovations

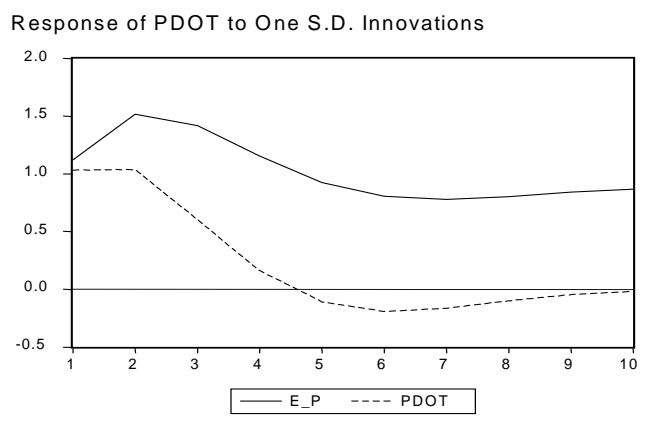

These results support the positive long-run relationship between the real fed funds rate and the earnings yield, which shows the long-run character of the relationship underlying the market response. This relationship indicates that an increase in the earnings yield will permanently raise the real fed funds rate, inducing the negative relation between stock prices and the real fed funds rate that is referred to here as the market response. However, the direction of causality is the opposite of the conventional view. Second, a positive shock to the real fed funds rate will rotate the long-term relation between yields, raising stock prices. This effect occurs with a three-year delay, however. The same sign of the effect is indicated by the EC term for the first equation in the left panel of Table 5 
and in the Granger causality result in Table 3. There this effect becomes insignificant when inflation is included in the estimation. This again points out that the leading relation from increases in the real fed funds rate to higher stock prices occurs because of the long-run negative relationship between inflation and stock prices and the delayed response of inflation to changes in the real fed funds rate.

Similar cointegration tests were conducted for the three variables: inflation, the real fed funds rate and the earnings yield. A search of the lag length for the dynamics of included lagged first-difference in the variables indicates that one lag is optimal. The criterion for this choice is a Likelihood Ratio test conducted assuming one or two cointegrating equations. ${ }^{24}$ With one lag, the cointegration test indicates the presence of two CEs. The Likelihood Ratio statistic for no CE, at most one CE and at most two CE are (critical values in parenthesis) 35.55 (1\%: 29.75), 17.76 (1\%: 16.31), and 1.30 (5\%: 3.84), respectively. The first two statistics are above both the five-percent and one-percent critical values, while the latter is not above either. Thus the tests indicate the presence of two significant CEs.

The normalized cointegration equations are:

$$
\begin{aligned}
& \text { E_P }-1.529 \text { PDOT }=0 \\
& (-13.20) \\
& \text { RFF }-0.385 \text { PDOT }=0
\end{aligned}
$$

The numbers in parentheses are t-statistics. The CE equations indicate significant longrun positive relationships between both the earnings yield and real fed funds rate and the

\footnotetext{
${ }^{24}$ The Chi-squared statistics for two and three lags are 12.330 and 8.901 for the model with two CEs and 15.145 and 9.299 for one CE, respectively. The critical value is 16.919 .
} 
earnings yield and inflation. These imply that the earnings yield in the long run is again about four (3.976) times the real fed funds rate $(\mathrm{t}=4.45)$. Thus these results also support a long run link from the longest to shortest real yields. These CE results also are nearly identical to those presented above for bivariate relations. The key difference between the VEC model for these CEs and those for the bivariate case is that, in the three variable system, there is a potential response of inflation to the real fed funds rate. This response is not significant according to the error correction coefficient. ${ }^{25}$ The long-run positive relation between inflation and the real fed funds rate shown in equation 1 is implicit in the two cointegrating relationships shown at the top of Table 5. Adding the insignificant dynamics of the relationships in the three-variable system does not alter the impulse response relationships shown in Figure 2.

The time series results in this section are much stronger than the causality results above and provide considerable insight into those results and the underlying economic relationships. First, they show that the market response—a positive relationship of the earnings yield and the real fed funds rate—is a long-run equilibrium relationship. Second, the error correction term, impulse-response function and earlier simple causality evidence show that this relationship arises in a dynamic context from shocks to stock prices causing the opposite change in the real fed funds rate. Positive shocks to the real fed funds rate, with a lag (see Tables1-3) induce increases in stock prices two years later according the first error-correction term in left panel of Table 5, the impulse-response

\footnotetext{
${ }^{25}$ The coefficient on the error correction term for the second cointegrating relationship in Equation 1 above is -0.234 , but it is not statistically significant $(\mathrm{t}=-1.61)$. In the impulse-response experiment, a onestandard deviation shock to the real federal funds rate ( 2.015 percentage points) reduces inflation by about 0.5 percentage points initially and after about five years.
} 
graph (top left) in Figure 2, function, and the simple causality result (Table 3).

According to the latter evidence, the significant positive effect of the real fed funds rate on stock prices occurs only due to inflation, which is reduced by an earlier increase in the real fed funds rate. Thus, increases in stock prices can be indicators of past success in attempting to control inflation, or of other forces reducing inflation. They are not sources or indicators of higher inflation currently or in the future.

\section{Does the Fed Already Take Equity Prices into Account?}

Despite the absence of an exploitable link between stock prices and policy, it is possible that equity prices already have had a systematic effect on policy-makers' efforts to set the fed funds rate in the past. To examine this, the Taylor Rule [see Taylor (1993) and 1999)] linking inflation and the GDP gap is estimated and current and lagged values of the earnings yield are added to test the hypothesis that the fed funds rate already responds to stock prices. The federal funds rate was unusually high in 1981 and this could affect the statistical results. For that reason, this unusual level is controlled for with the dummy variable D81, which is one in 1981 and zero otherwise. ${ }^{26}$ The GDP gap measure is the percentage excess of real GDP over potential GDP as estimated by the Congressional Budget Office.

The statistically significant information from the earnings yield for the federal funds rate is found to include a temporary contemporaneous effect that disappears one year later but is permanent after two years. The temporary and permanent effects are nearly the same.

\footnotetext{
${ }^{26}$ The use of D81 in the estimations here and below does not affect any of the conclusions. There is no structural shift in the estimates when this variable is included, but there is one when it is omitted, according to Chow tests.
} 
The estimate includes a significant first order autoregressive term whose coefficient is $0.683(\mathrm{t}=4.48)$.

$$
\begin{aligned}
& \mathrm{FF}=-0.431+0.522 \mathrm{FF}(-1)+0.408 \text { PDOT }+0.457 \mathrm{GAP}+0.309 \mathrm{D}\left(\mathrm{E} \_\mathrm{P}\right) \\
& (-0.37) \quad(3.85) \\
& \text { + 0.254 E_P(-2) + 2.460 D81 }
\end{aligned}
$$
Adjusted $\mathrm{R}^{2}=0.91$
S.E. $=0.910$
D.W. $=1.76$

The sign of the relationship is again the opposite of that advocated by proponents of a central bank response to stock prices. The dynamics show that, given the inflation rate and GDP gap, a rise in stock prices (fall in the earnings yield) will induce a cut in federal funds rate within the year. This effect is consistent with the simple causality evidence and the impulse-response results observed in the time series results above (bottom panel on left in Figure 2). ${ }^{27}$ It is also consistent with the long-run relation between the real fed funds rate and stock prices and with the error correction result in Table 6. ${ }^{28}$ The 1981 variable has no effect on the estimates, but without it, the stability of the coefficients in recursive estimates varies considerably and when it is included, the coefficients show little change.

\footnotetext{
${ }^{27}$ One might suspect that the sign of the stock price relationship reflects reverse causality. The evidence in Table 3 indicates that causality runs from the earnings yield to the fed funds rate with this positive relation and rejects the reverse direction of causality when inflation is included as it is here.

${ }^{28}$ Including stock prices has a material effect on the response of the fed funds rate to a rise in inflation. The equilibrium effect of a rise in inflation on the federal funds rate in equation 2, imposing the long-run relation between inflation and the earnings yield on the right hand side of Table 5 , is a 170 basis point rise per percentage point rise in inflation. This is not much different from the Taylor Rule response of 150 basis points. When equation 2 is estimated without stock price terms, the response falls to 111 basis points. Without either the stock price terms or D81 it is 144 basis points.
} 
It is likely that the Fed reaction reducing the fed funds rate when stock prices rise simply reflects the role of a third factor instead of a direct Fed reaction. For example, the Fed often appears to follow market interest rates in setting the federal funds rate. Since market interest rates positively reflect information about future inflation, just as stock prices do, but inversely, increases in inflationary expectations can give a higher fed funds rate and to reductions in stock prices.

This "wrong” sign is also observed when stock price measures are used directly in the reaction function instead of the earnings yield. First, when the log of the price earnings ratio (LPE) is used, the negative effect appears immediately and longer lags or dynamics are not significant (the AR coefficient is $0.740, \mathrm{t}=5.51$ ):

$$
\mathrm{FF}=1.549+0.487 \mathrm{FF}(-1)+0.420 \mathrm{PDOT}+0.382 \mathrm{GAP}-2.435 \mathrm{D}(\mathrm{LPE})+2.890 \mathrm{D} 81
$$
Adjusted $\mathrm{R}^{2}=0.90$
S.E. $=0.902$
D.W. $=1.86$

Each ten percentage point rise in stock prices relative to earnings reduces the fed funds rate by about 24 basis points, according to the estimate. ${ }^{29}$ The same tests were conducted using the log of the S\&P stock price. The contemporaneous term has a negative, but insignificant effect ( $\mathrm{t}=-\mathrm{0.22})$, but the first-difference is significant, as are both components. The constraint that the effects are equal and offsetting cannot be rejected $(\mathrm{t}=0.24)$. Again a rise in stock prices is associated with a decline in the fed funds rate

\footnotetext{
${ }^{29}$ When the level of the log of the PE ratio two years earlier is added to equation 3, comparable to the structure of equation 2, its coefficient, -1.612 , is marginally insignificant $(t=-2.00)$ and the contemporaneous first-difference is about the same $(-2.680, t=-3.33)$.
} 
and the effect is about the same as that in equation 2 , though it is temporary. ${ }^{30}$ The AR coefficient is 0.806 and its t-statistic is 7.20 .

$$
\mathrm{FF}=2.460+0.342 \mathrm{FF}(-1)+0.483 \mathrm{PDOT}+0.418 \mathrm{GAP}-2.736 \mathrm{D}(\mathrm{LSP})+2.767 \mathrm{D} 81
$$
Adjusted $\mathrm{R}^{2}=0.89$
S.E. $=1.024$
D.W. $=1.81$

Bernanke and Gertler (1999) also find a negative stock price effect on the federal funds

rate in a Taylor Rule estimate with quarterly data, though in their case the effect is

insignificant. $^{31}$

Rigoban and Sack (2001) conclude that a 5 percent rise in the S\&P 500 price index raises the three-month T-bill rate by 10.7 basis points. They argue that this is consistent with a Fed reaction. But their analysis of the Fed reaction traces the effect of a stock price rise

\footnotetext{
${ }^{30}$ When lags of the log of the S\&P stock price index replace the earnings yield in equation 2, two significant lags of the level of the stock price measure (one year and two year lags) are significant and have equal and opposite effects on the fed funds rate. The coefficient on the lagged change in the log of the stock price indicates that a one percent rise in stock prices raises the fed funds rate by 4.29 basis points $(\mathrm{t}=$ 3.21). In this case, a lagged value of the stock price change has a significant positive effect on the federal funds rate, contrary to the dynamics observed in equations 4 . The result is similar to that in equations 2 and 3 except that the initial negative effect of the stock price change is not significant $(t=0.01)$. The long delay and other evidence above of a quicker response makes this temporary effect likely spurious.

${ }^{31}$ The negative and insignificant discussed by Bernanke and Gertler (BG) is for the sum of effects over the current and five past months. They do not report the contemporaneous or lagged effect, nor indicate if any individual coefficients are significant and negative. Hayford and Malliaris (2001) also find a negative coefficient for stock prices and it is significant. They interpret the effect as a Greenspan-Fed effect, feeding the creation of a stock price bubble. Ending the estimation of equation 3 above in 1995 results in a coefficient on the stock price term that is slightly smaller in absolute value (-2.675) , but still significant ( $\mathrm{t}$ $=-2.08$ ). In Tatom (2002), the same negative and significant effect of stock prices on the fed funds rate is observed using monthly data. There an insignificant sum, as in BG, is obtained for additions of insignificant lags ranging from one to five months, but the contemporaneous term remains significant and negative in each case. It is likely that their insignificant negative result for the U.S. arises from the inclusion of several insignificant lagged effects of stock prices in the reported sum, just as would occur here. The interpretation of the negative coefficient on stock prices in Tatom (2002), as here, is not that it represents a policy effort to feed bubbles, but rather reflects the future favorable inflation news in increased current stock prices. BG also find a negative and significant stock price effect in Japan for the period from 1979 through 1986:06, though this effect reverses in the 1990s.
} 
on consumption spending and GDP and, via the latter, to a Fed reaction to an increase in the GDP gap, where the gap coefficient is around one. In this case, they argue, the Fed reaction would be 15 to 30 basis points. But this analysis does not suggest an independent reaction within a Taylor Rule context. Their analysis also does not take into account the changing size of the effect of a stock price change on GDP in such a framework. In fact, there is no significant correlation between the percentage change in the stock price and the change in the GDP gap at an annual frequency $(r=0.28$, critical value $=0.31$. The correlation coefficient for changes in the price-earnings ratio and in the gap is negative and also insignificant (-0.19).

Thus, it appears that the Rigoban and Sack evidence is consistent with the absence of past Fed reactions to stock price changes beyond any that might arise through a stock price effect on inflation or the GDP gap. If one alters their assumed reactions of inflation and the gap to stock prices, however, the implied Fed response to a change in stock prices would also be reversed. For example, suppose that the gap is unrelated to stock prices that inflation and stock prices are significantly inversely related. Then if the Fed responds to stock prices following the Rigoban and Sack argument, it would reduce interest rates when stock prices rise.

Even if the Fed could control equity prices in the long run, it would not be advisable. ${ }^{32}$

\footnotetext{
${ }^{32}$ Cecchetti et al. (2000) follow Smets (1997a, 1997b) in claiming a theoretical basis for a Fed reaction to stock prices. They examine three possible supply shocks to the asset and goods markets in Smets model. In only one of these will a Fed reaction to stock prices stabilize inflation. This shock is a permanent asset market shock that is unaccompanied by a goods market shock. An asset market shock that does not affect the goods market, and in a manner that offsets any inflation effect, is not easily imagined. In other cases, a Fed reaction would not stabilize inflation.
} 
Such an effort requires that the central bank know the appropriate measure or target. Second, such efforts presume that there is a politically acceptable mandate and justification for taking policy actions explicitly aimed at damaging the economic interest of some parties. It is difficult enough (technically, economically and politically) to conduct policy while minimizing such unintended consequences of policy. Is there a principle that allows a policy maker to intentionally inflict damage on stockholders without judicial review or compensation?

More important, the time series evidence above indicates that a fall in stock prices (rise in the earnings yield) reflects a subsequent rise in inflation. Should the Fed tighten in the face of higher inflation or ease in the face of the decline in stock prices associated with higher inflation? In the case of a rise in stock prices and beneficial effect on inflation, Fed tightening would seem unnecessary or inappropriate. Similarly when stock prices fall, worsening inflation, a focus on inflation would suggest that the Fed should not ease in response to the decline in stock prices.

The reaction function results provide one more body of evidence that proponents of a Fed reaction have got the direction of effects all wrong. If the Fed wants to influence stock prices in a way that furthers an inflation objective, then it would raise the fed funds rate when stock prices are "low" and reduce it when stock prices are "high.” But implicitly, at least, that is what the Fed has been doing in the past when claiming to fight inflation or maintain price stability. Inflation control maximizes stock prices. If the Fed could independently pursue a low fed funds, rate then stock prices could be boosted further 
according to the cointegration results here. An attempt to raise stock prices by lowering the fed funds rate, however, would run up against the fact that the preponderance of evidence (causality, error-correction and impulse-response function) shows that such an effort would lower stock prices (again because the inflation outlook would worsen). In any event, the time series and causality evidence concur that the Fed cannot control the real fed funds rate in the long run. The Fed can only influence the real fed funds rate in the short run, that is given current and past inflation rates (Table 3). ${ }^{33}$

\section{Summary}

The link between equity prices and monetary policy has become the subject of a rapidly growing literature due, in part, to the stellar performance of the U.S. equity market (19962000) and subsequent bear market, coupled with the increased exposure of households to equity wealth and risk. Some policy analysts suggest that the Fed should target the equity price or at least take it into account in its efforts to stabilize inflation, prices or other objectives. This article provides evidence on many of the issues raised by proposals that the Fed could or should attempt to influence stock prices. It shows that reacting to stock prices is unnecessary and likely to be stabilizing. Reacting in the direction currently advocated by many would actually be perverse. First, there is no contemporaneous correlation between the real fed funds rate and the real yield on stocks implicit in the PE ratio, either in levels or first-differences from 1959-2000. A strong negative correlation between the federal funds rate and the PE ratio arises from the significant correlation

\footnotetext{
${ }^{33}$ In Tatom (2002) the real fed funds rate is found to be stationary in monthly data from 1954 to 2001 . The annual evidence should reveal long-run relationships less noisily, but the degrees of freedom in annual data may technically be too small to allow rejection of a unit root. The implication of a stationary unit root is that policy cannot alter it in the long run.
} 
of each to inflation. This relationship is negative for the PE ratio and positive for the federal funds rate. Inflation also affects the relationship between stock prices and the fed funds rate found in simple causality tests, in times series evidence and in Fed reaction functions.

Simple causality tests favor a bi-directional relationship between the earnings yield and the nominal or real fed funds rate, but in each direction the relationship is exactly the opposite of that suggested by advocates of a stock price reaction. A rise in the fed funds rate raises future stock prices and a rise in stock prices leads to a lower real fed funds rate after two years, though the latter effect is only significant if inflation is held constant by including it in the test equation. Controlling for inflation, the simple causality test equations show that the Fed cannot influence stock prices. The time series evidence supports the absence of a contemporaneous correlation, showing that a positive shock to the real fed funds rate has no initial effect on the stock price.

There is evidence of a strong positive long-run relationship between the earnings yield and the real federal funds rate and that the latter has error-correcting properties. The significant long-run positive relationship indicates that, in the long run, stock prices are inversely related to the real fed funds rate, as the market response and a long-run positive relation between yields of various maturities would suggest. This long-run relation indicates that the equilibrium earnings yield is about four times the real federal funds rate. For an equilibrium real federal funds rate of about 2 percent, which some have suggested, the long-run earnings yield is about eight and equilibrium price-earnings ratio 
is about 12.5, far below levels seen since 1995. A second long-run equilibrium relation indicates that the earnings yield is positively related to inflation, supporting the hypothesis that stock prices are adversely affected by inflation. Together with the first long-run relation, there is an implied positive long-run relation between the real fed funds rate and inflation.

Overall, the evidence here rejects any ability of the Fed to influence stock prices in the long run by their setting of the fed funds rate. It also shows that Fed efforts to influence stock prices in the medium term would have the opposite effects to those proposed by advocates of a Fed reaction to stock prices. In the short run, within the year, there is no correlation between stock prices and the real fed funds rate. At best, stock prices are an indicator of inverse movements in inflation, not an appropriate or useful target of policy. A variant of the Taylor Rule relation suggests that the Fed has taken such indicator properties into account in the past. Whether they should have, or instead should have used stock price appreciations for timely “opportunistic disinflation,” is a strategy issue that goes beyond the scope of this paper.

What about stock market bubbles? Even if they do not have adverse effects on inflation, they presumably affect (“distort”) investment choices and the allocation of resources. Can monetary policy be used to address them? The time series evidence shows that an artificially low earnings yield, held down by a bubble, could be raised by a permanent shock to the real fed funds rate, but the required shock would be a decline in the real fed funds rate, fostering inflation. The response of the bubble would come only with a fairly 
long lag. Moreover, the Fed cannot permanently lower the real fed funds rate according to the evidence here. At least in the short to medium term, the evidence here provides no useful actions that could address bubbles. Longer term, actions to promote inflation could lower stock prices, but adjusted for the higher inflation, stock prices might still appear excessive.

There is a final implication of the empirical results here that bears on the recent popular and policy discussions of the role of stock prices in affecting overall economic performance. Most of this discussion has focused on the potential wealth effect on consumer spending. The permanent income hypothesis and the structure of the nation's wealth both suggest that undue attention has been paid to equity capital. Moreover there is no evidence that consumption grew unusually large relative to GDP in the 1990s or has fallen since mid 2000 as a result of stock price movements. Another channel of influence - the effect of stock prices in affecting the cost of capital—has been largely ignored. The results here suggest that stock price developments have played a significant role in holding down the cost of capital and inflation and implicitly in boosting investment and real GDP in 1996-2000. 


\section{References}

Bakshi, Gurdip S. and Zhiwu Chen (1996). "Inflation, Asset Prices, and the Term Structure of Interest Rates in Monetary Economies.” Review of Financial Studies 9: 24176.

Bank for International Settlements (1998). “ The Role of Asset Prices in the Formulation of Monetary Policy,” Basel: BIS Conference Papers, Vol. 5.

Barro, Robert J. (1996). “Inflation and Growth” Federal Reserve Bank of St. Louis Review 48 (3), May/June: 153-69.

Bernanke, Ben and Mark Gertler (1999). "Monetary Policy and Asset Price Volatility.” Federal Reserve Bank of Kansas City Economic Review IV: 17-51.

Booth, James R., and Lena Chua Booth (1997). "Economic Factors, Monetary Policy, and Expected Returns on Stocks and Bonds." Federal Reserve Bank of San Francisco Economic Review 2: 32-42.

Bullard, James B. and Eric Schaling (2002). "Why the Fed Should Ignore the Stock Market.” Federal Reserve Bank of St. Louis Economic Review March/April: 35.41.

Campbell, John Y. and Robert J. Shiller (1988). "Valuation Ratios and the Long-Run Stock Market Outlook.” Journal of Portfolio Management 24 (2), June: 11-26.

Cecchetti, Steven G., Hans Genberg, John Lipsky and Sushil Wadhwani (2000). “Asset Prices and Central Bank Policy.” Conference paper presented at " Central Banks and Asset Prices,” International Centre for Monetary and Banking Studies, Geneva, May 5.

Council of Economic Advisers (2001). Economic Report of the President. Washington D.C.: Government Printing Office.

Engel, Robert F. and C. W. J. Granger (1987). “ Co-Integration and Error Correction: Representation, Estimation and Testing.” Econometrica 55 (2), March: 251-76.

Fama, Eugene F. (1981). "Stock Returns, Real Activity, Inflation, and Money." American Economic Review 71: 545-65.

Fama, Eugene F. and Kenneth R. French (1989). "Stock Returns, Expected Returns, and Real Activity." Journal of Financial Economics 45: 1089-1108.

Feldstein, Martin (1981). “Inflation and the Stock Market.” American Economic Review September: 839-47. 
Gertler, Mark, Marvin Goodfriend, Otmar Issing and Luigi Spaventa (1998). “ Asset Prices and Monetary Policy: Four Views.” London: Centre for Economic Policy Research and the Bank for International Settlements.

Glassman, James K., and Kevin A. Hassett (2001). “Did the Fed’s Obsession with Stocks Cause it to Miss the Slowdown?” Wall Street Journal, January 5.

Greenspan, Alan (1996). "The Challenge of Monetary Policy in a Democratic Society.” Francis Boyer Lecture, American Enterprise Institute for Public Policy, December 5.

Hayford, Marc and A.G. Malliaris (2001). "Is the Federal Reserve Bank Stock Market Bubble Neutral?” In George G. Kaufman (Ed.), Asset Price Bubbles: Implications for Monetary Policy. Elsevier Science-JAI: 229-43.

Hess, Patrick J. and Bong-Soo Lee (1999). "Stock Returns and Inflation with Supply and Demand Shocks.” Review of Financial Studies 12: 1203-18.

Jensen, Gerald R., Jeffrey M. Mercer and Robert Johnson (1996). "Business Conditions, Monetary Policy, and Expected Security Returns." Journal of Financial Economics 40 (2), February: 213-37.

Miller, Marcus, Paul Weller and Lei Zhang (1999). "Moral Hazard and U.S. Stock Market: Has Mr. Greenspan Created a Bubble?” Department of Economics, Warwick University.

Modigliani, Franco and Robert Cohn (1979). "Inflation, Rational Valuation and the Market." Financial Analysts Journal March/April.

Prakken, Joel (2000). “Potential Productivity and the Stock Market.” Business Economics April. http://findarticles.com/p/articles/mi_m1094/is_2_35/ai_63607828/.

Rigoban, Roberto and Brian Sack (2001). "Measuring the Reaction of Monetary Policy to the Stock Market.” Board of Governors of the Federal Reserve, Finance and Economics Discussion Series, Working Paper No. 2001-14, April 19.

Sharpe, Steven A. (2002). "Reexamining Stock Price Valuation and Inflation: The Implications of Analysts' Earnings Forecasts.” The Review of Economics and Statistics 80 (4), November: 632-48.

Shen, Pu (2000). “The P/E Ratio and Stock Price Performance.” Federal Reserve Bank of Kansas City Economic Review 85 (4): 23-36.

Smets, Frank (1997a). “Asset Prices and Monetary Policy: Theory and Evidence.” Unpublished paper, Bank for International Settlements. 
Smets, Frank (1997b). " Financial Asset Prices and Monetary Policy: Theory and Evidence.” Centre for Economic Policy Research Working Paper No. 1751, November.

Stock, James H. and Mark Watson (2001). “Forecasting Output and Inflation: The Role of Asset Prices.” National Bureau of Economic Research Working Paper \# 8180, March.

Tatom, John A., and James E. Turley (1979). "Inflation and Taxes: Disincentives for Capital Formation.” Federal Reserve Bank of St. Louis Economic Review January. Reprinted in Federal Reserve Readings on Inflation, Federal Reserve Bank of New York, February: 167-73.

Tatom, John A. and Thomas Rose (2000). “ Are There Global Differences in Real Cash Rates? A Review of Some Long-Run Asset Price Relationships.” DePaul University Working Paper, November.

Tatom, John A. (2002). “ Stock Prices, Inflation and Monetary Policy.” Business Economics October: 7-19.

Taylor, John B. (1993). “Discretion vs. Policy Rule in Practice.” Carnegie-Rochester Conference Series on Public Policy 39: 195-214.

Taylor, John B. (1999). “A Historical Analysis of Monetary Policy Rules.” In John B. Taylor (Ed.), Monetary Policy Rule. Chicago: University of Chicago Press: 319-41. 